\title{
Morphotype diversity of Prorocentrum lima in the western part of Indonesian waters
}

\author{
RIANI WIDIARTI, NEVIATY PUTRI ZAMANI^, DIETRIECH GEOFFREY BENGEN, HAWIS MADDUPPA \\ Graduate School of Marine Science, Department of Marine Science and Technology, Faculty of Fisheries and Marine Sciences, Institut Pertanian Bogor. \\ Jl. Rasamala, Kampus IPB Darmaga, Bogor 16680, West Java, Indonesia. Tel./fax.: +62-251-8623644, `email: neviaty@apps.ipb.ac.id
}

Manuscript received: 21 November 2020. Revision accepted: 9 January 2021.

\begin{abstract}
Widiarti R, Zamani NP, Bengen DG, Madduppa H. 2021. Morphotype diversity of Prorocentrum lima in the western part of Indonesian waters. Biodiversitas 22: 607-614. Prorocentrum lima is one of the toxic benthic dinoflagellates, known to produce various toxins, including okadaic acid and dinophysis toxins. The species have a wide range of morphological variability, and possess morphotype diversity, which makes it essential to have detailed morphology observation for identification and other purposes. However, such comprehensive observation has never been reported from Indonesian waters. This study aims to determine the morphological characteristics (including pore size and number of pores) of $P$. lima morphotypes, in the western part of Indonesian waters (Bintan Island, Belitung Island, Seribu Islands, and Karimunjawa Islands). The results showed three different and unique morphotypes of $P$. lima, namely morphotype 1, morphotype 2, and morphotype 3. Three clusters were presented by Cluster Analysis, corresponded to the three morphotypes, which were Belitung Island clusters, Seribu Islands and Karimunjawa Islands cluster, and Bintan Island cluster, respectively. These findings support distribution of $P$. lima and its potential risk of toxicity in Indonesian waters, which prompts the necessity of conducting future research, to avoid the negative impact.
\end{abstract}

Keywords: Cluster Analysis, morphological variability, morphology characters, reef islands, toxic dinoflagellates

\section{INTRODUCTION}

Some benthic dinoflagellates produce toxic substances, which causes several poisonous syndromes experienced by humans or other mammals, which commonly occur after the consumption of various seafood products. Approximately nine species of Prorocentrum have been known to produce okadaic acid (OA) and dinophysis toxins (DTX's) (Hoppenrath et al. 2013; Hoppenrath et al. 2014), which causes Diarrhetic Shellfish Poisoning (DSP). Prorocentrum lima is one of the benthic dinoflagellates, known to produce those various toxins (Nishimura et al. 2019). Furthermore, P. lima associated with other toxic benthic dinoflagellates, Gamberdiscus toxicus, also causes Ciguatera Fish Poisoning (CFP) in tropical areas (Burkholder 1998; Lehane and Lewis 2000).

Prorocentrum cells show similar shape and size, making it necessary to have detailed feature observations of cell surface morphology, for identification and classification purposes (Faust 1990). Prorocentrum has been reported in Indonesian waters. For instance, in Seribu Islands (Penjaliran Barat Island, Pramuka Island, Panggang Island, Semak Daun Island, Pari Island, Air Island and Tidung Island) (Widiarti 2002; Widiarti 2011; Widiarti and Pudjiarto 2015), Belitung Island (Buyut Island, Kelayang Cape, and Keran Island) (Widiarti 2010), Bali waters (Kuta, Sanur, and Nusa Dua), Lombok (Gili Trawangan) (Skinner et al. 2011), west coast of South Sumatera and Bintan Island coast-Riau Islands (Thamrin 2014), Padang city beach waters (Dwivayana 2015; Eboni et al. 2015; Oktavian et al. 2017; Seygita et al. 2015), North Lombok (Gili Meno and Gili Air) (Widiarti et al. 2016a), South Lampung waters (Pahawang Besar Island and Kelagian Kecil Island) (Widiarti and Adi 2016), and Weh Island waters-North Aceh (Rubiah Island) (Widiarti et al. 2016b). However, no detailed observation on cell surface morphology has been recorded.

Prorocentrum lima has a wide range of morphological variability, and possesses morphotype diversity (Hoppenrath 2013; Zhang et al. 2015; Chomérat et al. 2018). The morphotype diversity of $P$. lima has been revealed by several studies, such as in South China Sea waters (Zhang et al. 2015) and Caribbean Sea waters (Chomérat et al. 2018) (Table 1). Zhang et al. (2015), showed the cell shape, cell length and width, ratio length and width (ratio L/W), pore shape, and the number of pores. Similarly, Chomérat et al. (2018) showed cell shape, cell length and width, ratio $\mathrm{L} / \mathrm{W}$, and pore shape and dimension. However, the studies lacked information on both pore dimension and number of pores, which should have been used to complete the database on morphotype diversity of $P$. lima. The morphotype diversity of $P$. lima, has never been reported in Indonesian waters. Therefore, this research is being conducted to determine the morphological characteristics (including pore size and number of pores) of $P$. lima morphotype, from several sites in the western part of Indonesian waters: Bintan Island, Belitung Island, Seribu Islands, and Karimunjawa Islands. 
Table 1. Prorocentrum lima characters by previous studies

\begin{tabular}{lcc}
\hline \multirow{2}{*}{ Characters } & \multicolumn{2}{c}{ Results } \\
\cline { 2 - 3 } & South China Sea Waters (Zhang et al. 2015) & Caribbean Sea Waters (Chomérat et al. 2018) \\
\hline Cell Shape & Ovate, broadly ovate, oblong oval, broadly oblong & Oblong oval, broadly ovate \\
Cells Length $(\mu \mathrm{m})$ & $32-48.1$ & $31.1-38.2$ \\
Cells Width $(\mu \mathrm{m})$ & $25.2-38.2$ & $27.8-32.3$ \\
Ratio L/W & $1.06-1.61$ & $1.10-1.36$ \\
Pore Size $(\mu \mathrm{m})$ & - & $0.4-0.8$ \\
Number of Pores & $28-94$ & - \\
(valve and marginal pores) & & round/ oval/ kidney-shaped \\
Pore Shape & round/ oblong/ kidney-shaped &
\end{tabular}

\section{MATERIALS AND METHODS}

\section{Study area}

Sampling was conducted from April to September 2018 in four islands, located in the western part of Indonesian waters, including Bintan Island, Belitung Island, Seribu Islands, and Karimunjawa Islands (Figure 1). The sampling locations focused on coral reefs with poor conditions, because it potentially provides a new surface for various macroalgae growth, where the toxic dinoflagellates are more likely to attach (deSylva 1994; Lehane and Lewis 2000). The coral reefs in all four locations have already been disrupted by domestic, tourism, and local fishery activities (Estradivari et al. 2009; Yusuf 2013; Susetiono et al. 2016), so that the macroalgae were also found abundantly in the areas. Sampling locations were situated on the eastern coast of Bintan Island, the northern coast of Belitung Island, Pramuka Island on Seribu Islands, and Karimunjawa Island on Karimunjawa Islands.

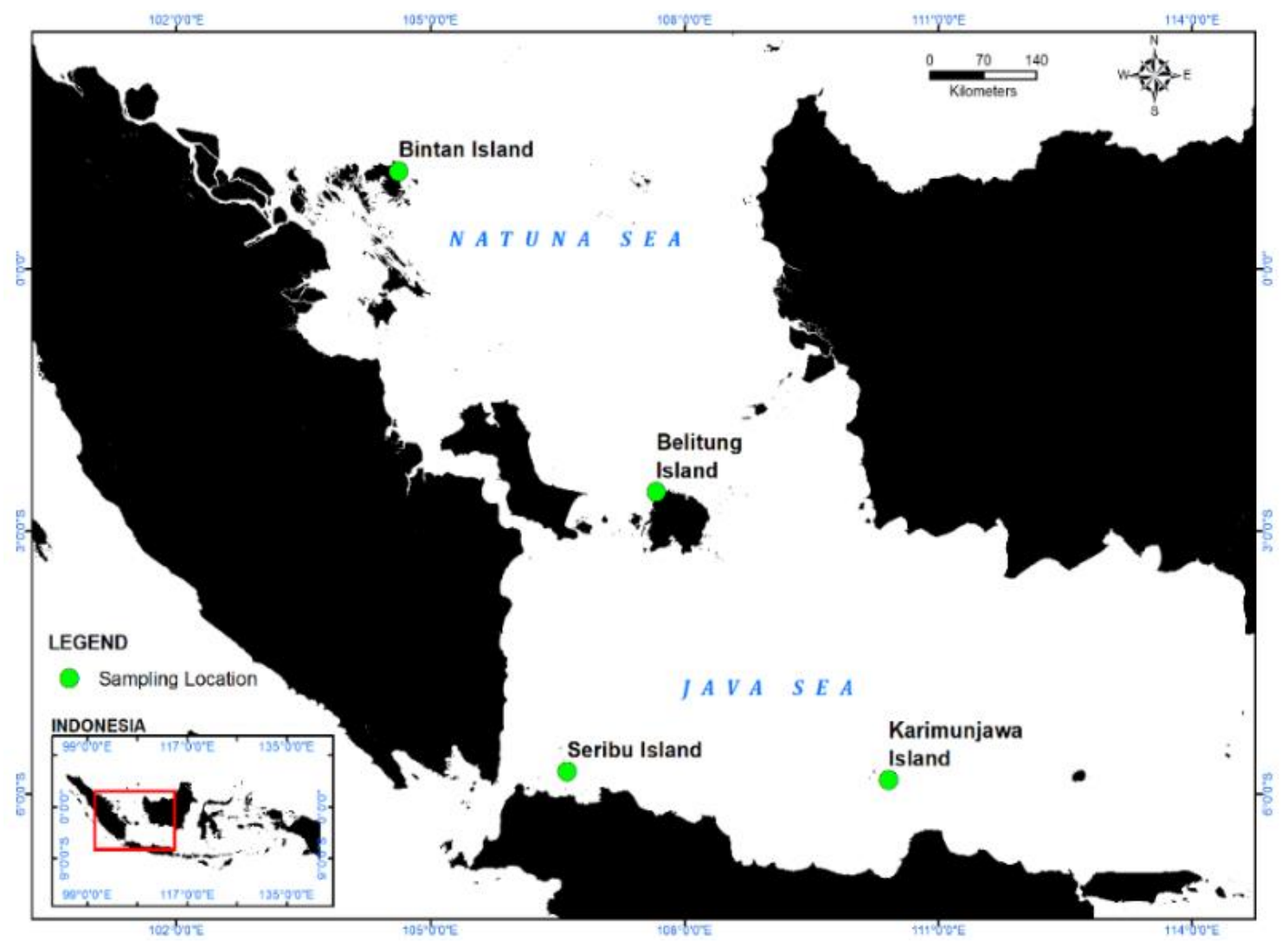

Figure 1. Sampling locations in Bintan Island (Station II), Belitung Island (Station IV), Seribu Islands (Station I), and Karimunjawa Islands (Station III) 


\section{Procedures}

Data-collection

The macroalgae collected, were only limited to Sargassum and Padina. As has been observed by Widiarti (2002), benthic dinoflagellates are commonly found attached to both macroalgae. Macroalgae's thallus was randomly harvested on the reef flat areas with $45 \mathrm{~cm}-100$ $\mathrm{cm}$ depth, and placed inside wide-mouthed plastic bottles containing ambient seawater (Tester et al. 2014). The whole process was conducted underwater (Tester et al. 2014; Jauzei et al. 2018), to avoid sample disruptions due to air and sunlight exposures.

After collection, plastic bottles containing macroalgae and seawater were shaken using vortex machine (1250 rpm for 1 minute), to detach benthic dinoflagellates from the surface of macroalgae. Furthermore, the samples were filtered through a series of sieves with a mesh size of 125 and $20 \mu \mathrm{m}$, to separate samples from sediments and other larger organisms. For morphological observation using LM and SEM, samples were fixed using glutaraldehyde to reach the final concentration of $4 \%(\mathrm{v} / \mathrm{v})$.

\section{Morphological-character-observation}

Cell shape and size were observed, by using a light microscope (LM) (Leica DM 500). The fixed cells were isolated using modified Pasteur pipette, dripped onto the object-glass, and sealed with a cover glass. The slides were then observed under a microscope with 200 magnification. Furthermore, cell length and width were measured digitally, using LEICA LAS EZ 2.0.

Cell pores (shape, size and the number of pores) and periflagellar area were observed, using Scanning Electron Microscope (SEM) (ZEISS with EVOIMA10 type). The isolated cells were dripped onto $2 \mathrm{x} 1 \mathrm{~cm}^{2}$ filter paper (Whatman $125 \mathrm{~mm}$, pore size $3 \mu \mathrm{m}$ ), which was already placed on top of the object-glass covered with carbon tape. The samples were air-dried and coated with gold $(\mathrm{Au})$, using Sputter Coater (Quorum type Q150R ES), with 20 (mA) Sputter Current and 60 second Sputter Time. After the coating process, SEM samples were analyzed, and the images were taken using the SE (Secondary Electron) detector, with $8.0 \mathrm{~mm}$ Working Distance (WD) and EHT $16.00 \mathrm{kV}$. Pore length and width measurements were obtained using biometric program tpsUtil32 dan tpsDig232.

\section{Environmental-factors-measurement}

During sample collections within the four locations, measurements of the environmental condition were also conducted. These measurements included, salinity by refractometer (ATAGO), water temperature and dissolved oxygen by DO-meter (HANNA), light intensity by luxmeter (LX-1010B), water acidity by $\mathrm{pH}$ indicator (MColorpHast 6.5-10), water current by current meter, with nitrate and phosphate using APHA Analysis Method (2012) in the laboratory.

\section{Data analysis}

Morphological character data were tabulated, and compared with morphotypes grouping suggested by Zhang et al. (2015). Character similarity of each Operational Taxonomic Units (OTU) was analyzed by cluster analysis methods, with the use of Hierarchical Cluster Analysis, which was further processed by $\mathrm{R}$ version 3.6.2. The cluster analysis results were presented in the form of a dendrogram (treelike diagram) (Sneath 2005).

\section{RESULTS AND DISCUSSION}

All samples collected from the four sampling locations, showed that Prorocentrum lima cells possessed ovoid/ovate shape, visible pyrenoid at the center of the cell, scattered pores on both valves (except in the center of the cell), and V-shaped periflagellar areas with 8 platelet plates (Figure 2).

Based on the observation using LM, the length and width of the cells ranged from 35.49-44.94 $\mu \mathrm{m}$ (mean $38.27 \mu \mathrm{m}$, s.d $2.77 \mu \mathrm{m}, \mathrm{n}=20$ ), and 25.57-31.56 $\mu \mathrm{m}$ (mean $28.63 \mu \mathrm{m}$, s.d. $2.05 \mu \mathrm{m}, \mathrm{n}=20$ ), with the ratio $\mathrm{L} / \mathrm{W}$ being 1.17-1.44 (mean 1.34, s.d 0.09, $\mathrm{n}=20$ ). Furthermore, based on the observation using SEM, the pore length and width ranged from $0.21-0.40 \mu \mathrm{m}$ (mean $0.30 \mu \mathrm{m}$, s.d $0.05 \mu \mathrm{m}, \mathrm{n}$ $=20$ ), and 0.15-0.33 $\mu \mathrm{m}$ (mean $0.21 \mu \mathrm{m}$, s.d $0.05 \mu \mathrm{m}, \mathrm{n}=$ 20 ). The number of pores observed was around 40-68 (mean 50.3, s.d 9.2, $\mathrm{n}=20$ ), with the valve shape being round to kidney-shaped (Table 2). Due to the unclear images obtained by SEM, the observation of pores in this study was based only on valve pores.
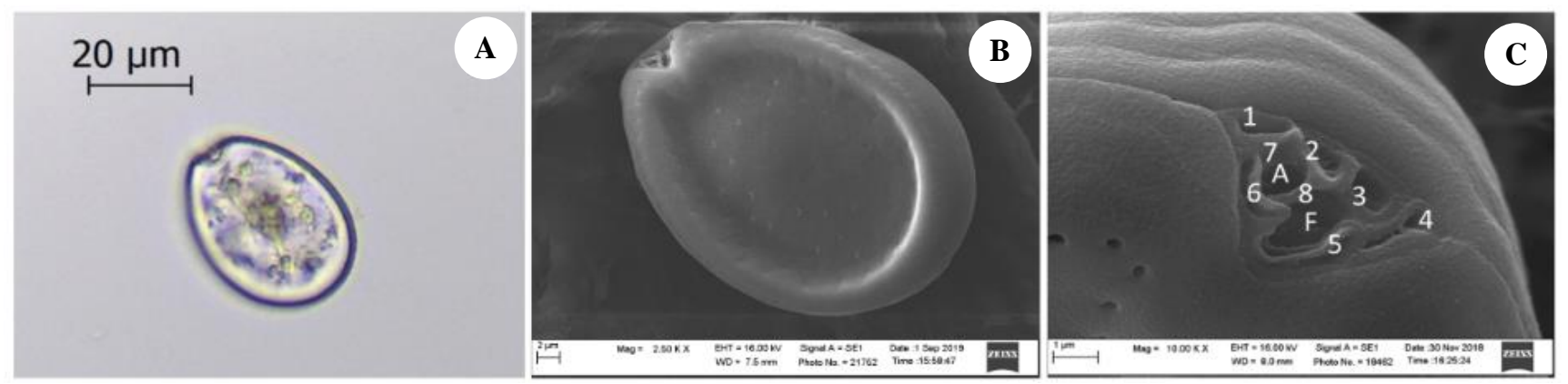

Figure 2. Morphology characters of Prorocentrum lima using LM and SEM. A. Cell shape, pyrenoid in the center of the cell; B. Scattered pores except in the center of the cell; C. V-shaped periflagellar area with eight platelets 
Table 2. Morphology characters of Prorocentrum lima from all sampling locations $(\mathrm{n}=20)$

\begin{tabular}{|c|c|c|c|c|}
\hline \multirow{2}{*}{ Characters } & \multicolumn{4}{|c|}{ Sampling locations } \\
\hline & Seribu Islands & Bintan Island & Karimunjawa Islands & Belitung Island \\
\hline Cell Length $(\mu \mathrm{m})$ & $36.05-41.16$ & $40.26-44.94$ & $35.81-37.30$ & $35.49-37.79$ \\
\hline Cell Width $(\mu \mathrm{m})$ & $26.32-30.05$ & $29.45-31.56$ & $25.57-27.17$ & $28.86-31.51$ \\
\hline Ratio L/W & $1.33-1.42$ & $1.34-1.42$ & $1.35-1.44$ & $1.17-1.23$ \\
\hline Pore Length $(\mu \mathrm{m})$ & $0.29-0.40$ & $0.28-0.37$ & $0.23-0.31$ & $0.21-0.38$ \\
\hline Pore Width $(\mu \mathrm{m})$ & $0.23-0.33$ & $0.19-0.21$ & $0.15-0.19$ & $0.16-0.32$ \\
\hline Number of Pores (Valve Pores) & $40-48$ & $51-68$ & $42-53$ & $48-59$ \\
\hline Pore Shape & round/kidney-shaped & round/kidney-shaped & round/kidney-shaped & round \\
\hline
\end{tabular}

Further examination using Cluster Analysis, showed that the optimal number of the cluster could be obtained through the use of a Scree and Silhouette Plot. There were three optimal numbers of the cluster, showed by the elbow and peak points at the Scree and Silhouette Plots, respectively (both showed cluster $\mathrm{k}=3$ at axes 1 ). Cluster Analysis showed three clusters, where cluster 1 consists of four members, cluster 2 consists of ten members, and cluster 3 consists of six members. Cluster 1 represented by I3, IV1, IV4 and IV5, was described as one $P$. lima specimens at station 1 (Seribu Islands), and three specimens at station 4 (Belitung Island). Based on the cluster dendrogram, three specimens from Belitung Island were closely related to each other (Figure 3 ). Cluster 1 was characterized by a low mean value of ratio L/W. Specimens of $P$. lima obtained from Belitung Island possessed the lowest ratio $\mathrm{L} / \mathrm{W}$ values compared to other sampling locations (Table 2).

Cluster 2 represented by I1, I2, I5, III1, III2, III3, III4, III5, IV2 and IV3, which were described as three P. lima specimens at station 1 (Seribu Islands), all specimens at station 3 (Karimunjawa Islands) and two specimens at station 4 (Belitung Island). Based on the cluster dendrogram (Fig 3), three specimens from the Seribu Islands were closely related to all specimens from Karimunjawa Islands. At cluster 2, variables III1, III2, III3, III4 and III5 possessed closer distance, compared to other members of the cluster, which is showed by the shorter height of Euclidian distance at axes 2. Cluster 2 was characterized by the lowest mean values of cell length (36.4040), cell width (26.9190), pore length (0.2740), and pore width (0.1920). The $P$. lima cells in Seribu Islands possessed high values of pore dimensions $(0.29-0.40 \mu \mathrm{m}$ in length and $0.23-0.33 \mu \mathrm{m}$ in width), while showing low mean values of both characters, based on Cluster Analysis. These occurred as a mean result of pore dimensions between values from Seribu Islands and from the Karimunjawa Islands, which possessed the lowest values from all sampling locations $(0.23-0.31 \mu \mathrm{m}$ in length and $0.15-0.19 \mu \mathrm{m}$ in width) (Table 3 ).

Cluster 3 represented by I4, II1, II2, II3, II4 and II5, was described as one $P$. lima specimens at station 1 and five $P$. lima specimens at station 2 (Seribu Islands and Bintan Island), respectively. Based on the cluster dendrogram, four specimens from Bintan Island, were closely related to each other (Figure 3). Cluster 3 was characterized by a high mean value of ratio $\mathrm{L} / \mathrm{W}$, and the number of pores. In this research, $P$. lima specimens from Bintan Island possessed the highest pore number (51-68), compared to other sampling locations (Table 3). In previous studies, different pore shapes were frequently observed in one cell (Hoppenrath et al. 2013; Zhang et al. 2015), same as this study where both round and kidneyshaped pores, were also found in one cell. Pore shape character was not used as a variable in the Cluster Analysis.

Environmental parameters data in four different sampling locations showed, salinity values ranged from 30$34.7 \%$, temperature from $27.5-30.8^{\circ} \mathrm{C}$, dissolved oxygen (DO) from 7.6-13.5 ppm, light intensity from 1392-46983 lux, acidity from 7.1-7.8, water current from 0.039-0.115 $\mathrm{ms}^{-1}$, nitrate from $0.087-0.101 \mathrm{mg} . \mathrm{L}^{-1}$ and phosphate from 0.002-0.009 mg.L $\mathrm{L}^{-1}$ (Table 4).

\section{Cluster Dendrogram}

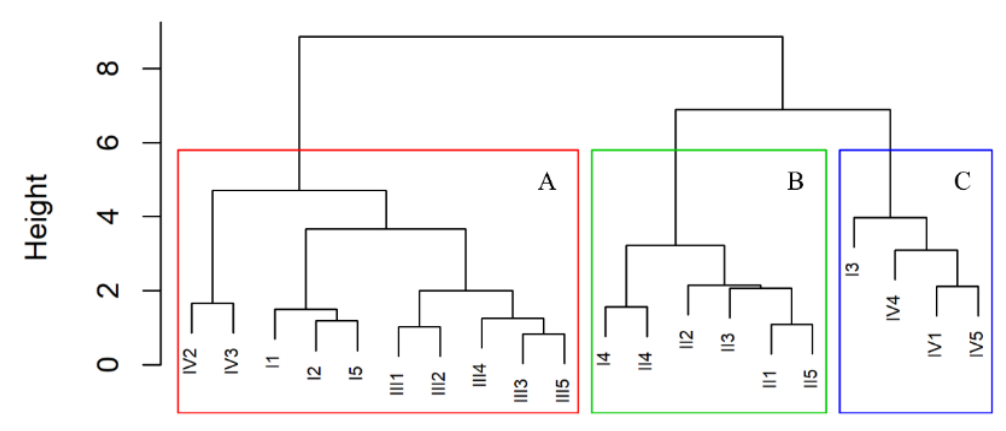

Figure 3. Closely related groups at each cluster based on Euclidian distance. A. Cluster 2, Seribu Islands and Karimunjawa Islands; B. Cluster 3, Bintan Island; C. Cluster 1, Belitung Island 
Table 3. Mean values of morphology characteristic from each cluster $(n=20)$

\begin{tabular}{ccccccc}
\hline Group & Cell Length & Cell Width & Ratio L/W & Pore Length & Pore Width & Pore Number \\
\hline $1(\mathrm{n}=4)$ & 37.5175 & 30.66500 & 1.225000 & 0.3475 & 0.2775000 & 49.25 \\
$2(\mathrm{n}=10)$ & 36.4040 & 26.91900 & 1.356000 & 0.2740 & 0.1920000 & 45.20 \\
$3(\mathrm{n}=4)$ & 41.8750 & 30.12667 & 1.388333 & 0.3150 & 0.2066667 & 59.50 \\
\hline
\end{tabular}

Table 4. The average values of environmental factors measurement at four sampling stations

\begin{tabular}{|c|c|c|c|c|c|c|c|c|}
\hline Location & Salinity & $\begin{array}{c}\text { Temperature } \\
\left({ }^{\circ} \mathrm{C}\right)\end{array}$ & $\begin{array}{c}\text { DO } \\
(\mathrm{ppm})\end{array}$ & $\begin{array}{c}\text { Light } \\
\text { (lux) }\end{array}$ & pH & $\begin{array}{c}\text { Water current } \\
\left(\mathrm{ms}^{-1}\right)\end{array}$ & $\begin{array}{l}\text { Nitrate } \\
(\text { mg.L }\end{array}$ & $\begin{array}{c}\text { Phosphate } \\
\left(\text { mg.L } .^{-1}\right)\end{array}$ \\
\hline Seribu Islands (Station I) & 30.0 & 27.5 & 13.4 & 1392 & 7.8 & 0.048 & 0.094 & 0.002 \\
\hline Bintan Island (Station II) & 32.0 & 30.5 & 7.6 & 37270 & 7.1 & 0.039 & 0.087 & 0.009 \\
\hline Karimunjawa Islands (Station III) & 34.7 & 30.8 & 11.7 & 30850 & 7.2 & 0.115 & 0.101 & 0.003 \\
\hline Belitung Island (Station IV) & 34.0 & 29.6 & 13.5 & 46983 & 7.2 & 0.055 & 0.098 & 0.003 \\
\hline
\end{tabular}

The cells of $P$. lima have specific morphological characters, which are generally used to differentiate this Prorocentrum species from others. Those characters were symmetric cells with oblong oval, ovoid (Hoppenrath et al. 2013) or ovate shape (Zhang et al. 2015), visible pyrenoid in the center of the cell, scattered pores on both valves but void in the center of the cell (Fukuyo 1981; Faust 1990), and wide $\mathrm{V}$-shaped periflagellar areas consisting of 8 platelet plates (Hoppenrath et al. 2013; Zhang et al. 2015). In this study, observation using LM or SEM showed that benthic dinoflagellates obtained from Bintan Island, Belitung Island, Seribu Islands, and Karimunjawa Islands, possessed all the mentioned characters, so all the specimens collected could be defined as P. lima (Figure 2).

Based on the observation using LM, the cells showed normal and broadly ovate shape, with dimensions ranging from 35.49-44.94 $\mu \mathrm{m}$ (mean $38.27 \mu \mathrm{m}$, s.d $2.77 \mu \mathrm{m}, \mathrm{n}=$ 20) and 25.57-31.56 $\mu \mathrm{m}$ (mean $28.63 \mu \mathrm{m}$, s.d. $2.05 \mu \mathrm{m}, \mathrm{n}=$ 20) (Table 2). The cell sizes were within the range of $P$. lima length and width, which were at 31-47 $\mu \mathrm{m}$ and $22-40$ $\mu \mathrm{m}$ for Grzebyk et al. (1998), and 30-57 $\mu \mathrm{m}$ and 21-46 $\mu \mathrm{m}$ for Zhang et al. (2015). The ratio L/W from this study was 1.17-1.44 (mean 1.34, s.d 0.09, $\mathrm{n}=20$ ), which was also within the range of $P$. lima by Zhang et al. (2015) at 1.061.61, or that of Chomérat et al. (2018) at 1.10-1.36. Based on the observation using SEM, the cells showed pore length and width ranging from 0.21-0.40 $\mu \mathrm{m}$ (mean 0.30 $\mu \mathrm{m}$, s.d $0.05 \mu \mathrm{m}, \mathrm{n}=20$ ), and $0.15-0.33 \mu \mathrm{m}$ (mean 0.21 $\mu \mathrm{m}$, s.d $0.05 \mu \mathrm{m}, \mathrm{n}=20$ ), which were still within the range of $0.37 \mu \mathrm{m}$ by Nagahama and Fukuyo (2005), and 0.31$0.70 \mu \mathrm{m}$ by Hoppenrath et al. (2013). The number of pores obtained in this study ranged from 40-68 (mean 50.3, s.d 9.2, $\mathrm{n}=20$ ), relatively close to Zhang et al. (2015), which was 42-94.

$P$. lima showed five morphotypes, which differ in cell length, cell width, ratio $\mathrm{L} / \mathrm{W}$, and pore number (Zhang et al. 2015). Meanwhile, other characters such as pore shape, pore length, and pore width, were also characters that could help differentiate morphotype (Grzebyk et al. 1998). Observation on $P$. lima cells obtained from four sampling locations also showed different results, and descriptions on each sampling locations are as follows,

\section{Seribu Islands}

Observation on P. lima cells obtained in Seribu Islands waters showed ovate shape, cell length and width ranging from 36.05-41.16 $\mu \mathrm{m}$ (mean $38.39 \mu \mathrm{m}$, s.d. $2.17 \mu \mathrm{m}, \mathrm{n}=5$ ) and 26.32-30.05 $\mu \mathrm{m}$ (mean $27.90 \mu \mathrm{m}$, s.d. $1.58 \mu \mathrm{m}, \mathrm{n}=5$ ), respectively, with the ratio $\mathrm{L} / \mathrm{W}$ from $1.33-1.42$ (mean 1.38 , s.d. $0.04, \mathrm{n}=5$ ). The shape and size were within the range of $P$. lima "morphotype 2" by Zhang et al. (2015), with cell length and width ranging from $36.8-40.0 \mu \mathrm{m}$, and 25.6-28.9 $\mu \mathrm{m}$, respectively, and the ratio $\mathrm{L} / \mathrm{W}$ at 1.33-1.45 (Table 2, Figure 4.1). However, observation on pores showed different results, where the pore number with 40 48 (mean 44, s.d. 5.2, $\mathrm{n}=5$ ) is closely within the range of "morphotype 1" by Zhang et al. (2015), which was 42-84. The shape of pores observed in this study were round to kidney-shaped, showing pore shape variation of "morphotype 2" which is round, and "morphotype 3," which is kidney-shaped/oblong.

\section{Bintan Island}

Observation on P. lima cells collected in Bintan Island waters showed ovate shape, cell length and width ranging from 40.26-44.94 $\mu \mathrm{m}$ (mean $42.02 \mu \mathrm{m}$, s.d. $1.86 \mu \mathrm{m}, \mathrm{n}=5$ ) and 29.45-31.56 $\mu \mathrm{m}$ (mean $30.34 \mu \mathrm{m}$, s.d. $0.87 \mu \mathrm{m}, \mathrm{n}=5$ ), respectively, with the ratio $\mathrm{L} / \mathrm{W}$ from 1.34-1.42 (mean 1.38 , s.d. $0.03, \mathrm{n}=5$ ). The shape and size were within the range of $P$. lima "morphotype 3" by Zhang et al. (2015), with cell length and width at 37.5-48.1 $\mu \mathrm{m}$ and 27.3-38.2 $\mu \mathrm{m}$, respectively, and the ratio $\mathrm{L} / \mathrm{W}$ at 1.23-1.5 1 (Table 2, Figure 4.2). Furthermore, observation on pores showed number of pores with a count of 51-68 (mean 61.2, s.d 6.3, $\mathrm{n}=5$ ), which corresponds to "morphotype 2" by Zhang et al. (2015). The shape of pores observed in this study were round to kidney-shaped, showing pore shape variation of "morphotype 2" which is round, and "morphotype 3," which is kidney-shaped/oblong.

\section{Karimunjawa Islands}

Observation on $P$. lima cells obtained in Karimunjawa Islands waters showed ovate shape, cell length and width ranging from $35.81-37.30 \mu \mathrm{m}$ (mean $36.43 \mu \mathrm{m}$, s.d. 0.57 $\mu \mathrm{m}, \mathrm{n}=5$ ) and 25.57-27.17 $\mu \mathrm{m}$ (mean $26.11 \mu \mathrm{m}$, s.d. 0.65 
$\mu \mathrm{m}, \mathrm{n}=5)$, respectively, with the ratio $\mathrm{L} / \mathrm{W}$ from $1.35-1.44$ (mean 1.40 , s.d. $0.04, \mathrm{n}=5$ ). The shape and size were within the range of $P$. lima "morphotype 2 " by Zhang et al. (2015), with cell length and width from $36.8-40.0 \mu \mathrm{m}$ and 25.6-28.9 $\mu \mathrm{m}$, respectively, and the ratio L/W from 1.331.45 (Table 2, Figure 4.3). Furthermore, observation on pores showed number of pores with a count of 42-53 (mean
47.8, s.d. 4.2, $\mathrm{n}=5$ ), corresponds to "morphotype 1 " by Zhang et al. (2015), which was 42-84. The shape of pores observed in this study were round to kidney-shaped, showing pore shape variation of "morphotype 2 " which is round, and "morphotype 3," which is kidneyshaped/oblong.

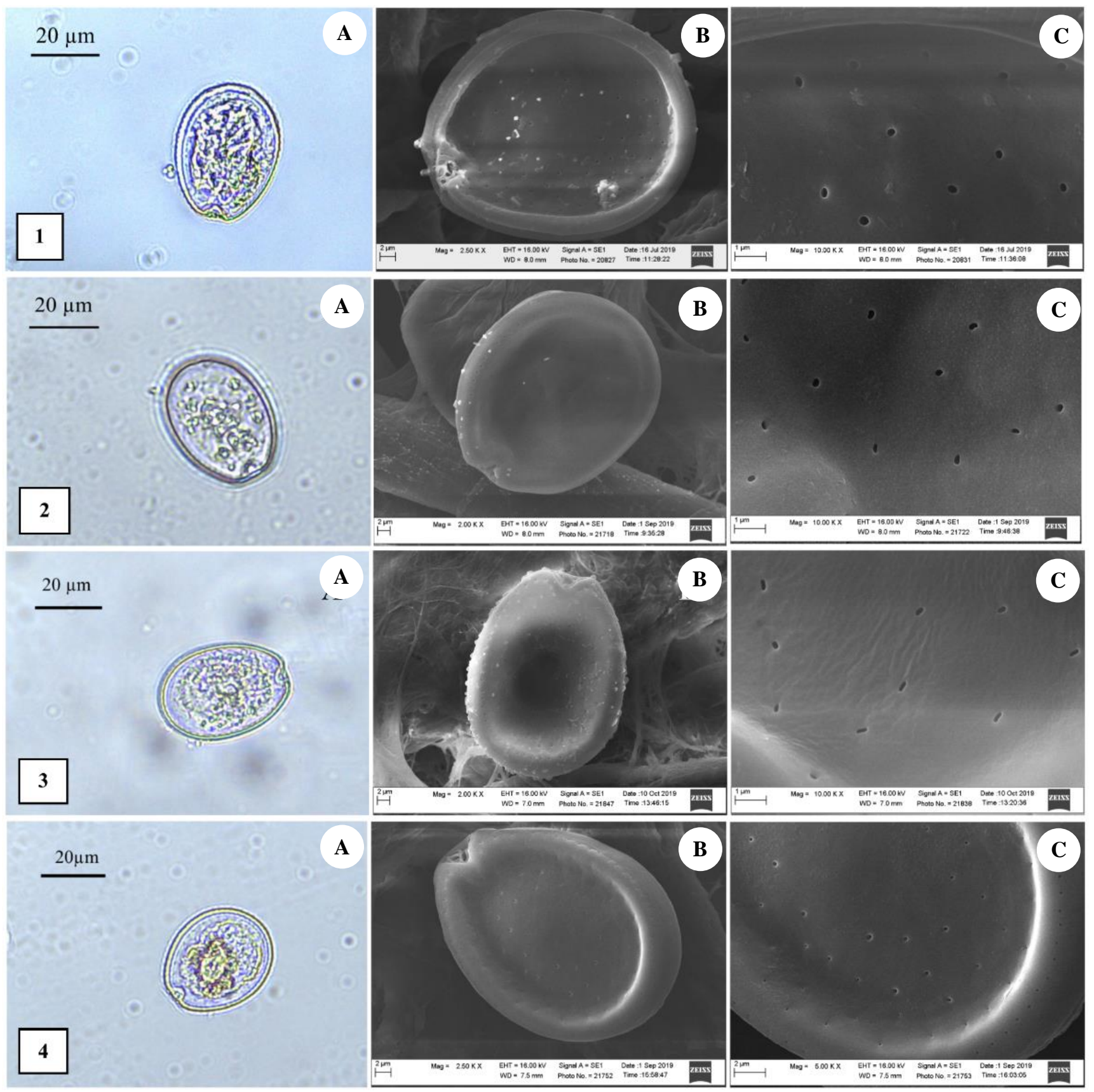

Figure 4. Morphology characters of Prorocentrum lima. 1. Seribu Islands. 2. Bintan Island. 3. Karimunjawa Islands. 4. Belitung Island. A. Cell shape and size under LM observation; B. Cell shape and size under SEM observation; C. Pore shape and size observation using SEM 


\section{Belitung Island}

Observation on P. lima cells obtained in Belitung Island waters showed broadly ovate shape, cell length and width ranging from 35.49-37.79 $\mu \mathrm{m}$ (mean $36.24 \mu \mathrm{m}$, s.d. 0.94 $\mu \mathrm{m}, \mathrm{n}=5$ ) and 28.86-31.51 $\mu \mathrm{m}$ (mean $30.17 \mu \mathrm{m}$, s.d. 1.05 $\mu \mathrm{m}, \mathrm{n}=5$ ), respectively, with the ratio $\mathrm{L} / \mathrm{W}$ from 1.17-1.23 (mean 1.20 , s.d $0.02, \mathrm{n}=5$ ). The shape and size were within the range of $P$. lima "morphotype 1" by Zhang et al. (2015), with cell length and width from 32.0-44.4 $\mu \mathrm{m}$, and 27.3-36.5 $\mu \mathrm{m}$, respectively, and the ratio L/W from 1.061.36 (Table 2, Figure 4.4). Furthermore, observation on pores showed number of pores with a count of 48-59 (mean 48.2, s.d. $10.4, \mathrm{n}=5$ ), corresponds to "morphotype 1 " by Zhang et al. (2015), which was 42-84. The shape of pore observed in this study was round, and similar to that of "morphotype 1".

Prorocentrum lima is known as a common species, widely distributed in tropical, subtropical and temperate waters (Hoppenrath et al. 2013; Nishimura et al. 2019). In this study, the cells were found in all sampling locations. Previous studies showed that $P$. lima was also found in several locations in Indonesian waters, namely Seribu Islands (Widiarti 2002; Widiarti 2011; Widiarti and Pudjiarto 2015), Belitung Island (Widiarti 2010), North Lombok (Widiarti et al. 2016a), South Lampung waters (Widiarti and Adi 2016) and Weh Island waters-North Aceh (Widiarti et al. 2016b), with environmental condition ranging from $28-33{ }^{\circ} \mathrm{C}$ for temperature, $26.0-34.5 \%$ for salinity, 6.5-7.4 for water acidity, $6.17-8.30 \mathrm{ppm}$ for dissolved oxygen, and $<0.1-0.2 \mathrm{~ms}^{-1}$ for water current. The environmental data measured in this study, also showed similar range of values, which were temperature from 27.0$31.3^{\circ} \mathrm{C}$, salinity from $30-35 \%$, water acidity from $6.5-7.9$, dissolved oxygen (DO) from 6.1-14.0 ppm, and water current from 0.0001-0.196 ms-1 (Table 4). All of the sampling locations showed relatively slow water current and high concentration level of nitrate (0.087-0.101 mg.L1) and phosphate (0.002-0.009 mg.L-1). Nitrate concentrations in the four locations, were above the water quality standard from the Ministry of Forestry and Environment for marine biota, which is $0.002 \mathrm{mg} / \mathrm{L}$ (Ministry of Forestry and Environment 2004). The slow water current and high level of nutrients, are likely to become factors that enhance eutrophication in the waters, as the potency of $P$. lima blooms should be at alert. The study on the density of $P$. lima in Tanjung Gelam, Karimunjawa Islands waters, showed that the abundance of cells obtained in the area, correlates to the higher phosphate value in the waters (Widiarti et al. 2018).

Due to the morphological observations and morphotype grouping by Zhang et al. (2015), the P. lima in this study could be determined into three morphotypes, namely morphotype 1 for specimens collected from Belitung Islands, morphotype 2 for specimens collected from Seribu Islands and Karimunjawa Islands, and morphotype 3 for specimens collected from Bintan Island (Table 2). All three morphotypes corresponded to those of the clusters based on Cluster Analysis, which were the Belitung Island clusters, the Seribu Islands and Karimunjawa Islands cluster, and the Bintan Island cluster, respectively.
The results of this study prompt the necessity of conducting an abundance survey, establishing strains, toxins and molecular phylogenetic analysis, and growth experiment, to assess the negative impact in the future.

\section{ACKNOWLEDGEMENTS}

The authors kindly express gratitude to the Scholarship for Doctoral Program (BUDI-DN) by Ministry of Finance and Ministry of Research Technology and Higher Education, the Republic of Indonesia, for funding the study and research, and colleagues from Department of Biology, Universitas Indonesia, for the assistance during sampling collection. Also, the authors are grateful to the Bioimaging Laboratory staffs at the Department of Biology, Universitas Indonesia, and Nanotechnology Laboratory staff from Research and Development Center of Agricultural Postharvest (R. Idris Suryadi), for observation and images collection using LM and SEM, with further gratitude to the GIS laboratory staff (Satria Indratmoko) and Statistic Clinique at FMIPA, Universitas Indonesia, Depok.

\section{REFERENCES}

Burkholder JM. 1998. Implications of harmful microalgae and heterotrophic dinoflagellates in management of sustainable marine fisheries. Ecological Applications 8 (1): S37-S62.

Chomérat N, Bilien G, Zentz F. 2018. A taxonomical study of Prorocentrum species (Prorocentrales, Dinophyceae) from Anse Dufour (Martinique Island, eastern Carribean Sea). Mar Biodiv 49 (3): 1299-1319.

Dwivayana TMS, Thamrin, Efriyeldi. 2015. Analysis of the abundance of benthic dinoflagellate on the artificial substrate at Padang City waters, West Sumatera. Jurnal Ilmu Lingkungan 9 (2): 122-130. DOI: 10.31258/jil.9.2.p.122-130. [Indonesian]

Eboni W, Thamrin, Mubarak. 2015. The distribution of toxic benthic dinoflagellate Gambierdiscus sp., Prorocentrum sp. and Ostreopsis sp. on Sargassum sp. in the coastal of Nipah River, Pesisir Selatan Regency, West Sumatra Province. Jurnal Online Mahasiswa 2 (1): 112. [Indonesian]

Estradivari, Setyawan E, Yusri S. 2009. Jakarta's Coral Reef: Long Term Observation on Coral Reef at Seribu Islands (2003-2007). Indonesian Coral Reef Foundation, Jakarta. [Indonesian]

Faust MA. 1990. Morphologic details of six benthic species of Prorocentrum (Pyrrophyta) from a mangrove island, Twin Cays, Belize, including two new species. J Phycol 26 (3): 548-558. DOI: 10.1111/j.0022-3646.1990.00548.x

Fukuyo Y. 1981. Taxonomical study on benthic dinoflagellates collected in coral reefs. Bull Japan Soc Sci Fish 47 (8): 967-978.

Grzebyk D, Sako Y, Berland B. 1998. Phylogenetic analysis of nine species of Prorocentrum (Dinophyceae) inferred from 18S Ribosomal DNA sequences, morphological comparisons, and description of Prorocentrum panamensis, sp. Nov. J Phycol 34 (6): 1055-1068. DOI: $10.1046 /$ j.1529-8817.1998.341055.x

Hoppenrath M, Chomérat M, Horiguchi T, Schweikert M, Nagahama Y, Murray S. 2013. Taxonomy and phylogeny of the benthic Prorocentrum species (Dinophyceae)-A proposal and review. Harmful Algae 27: 1-28. DOI: 10.1016/j.hal.2013.03.006

Hoppenrath M, Murray SA, Chomérat N, Horiguchi T. 2014. Marine Benthic Dinoflagellate: Unveiling Their Worldwide Biodiversity. Senckenberg-Reihe, Germany.

Jauzei C, Açaf L, Accoroni S, Asnaghi V, Fricke A, Hachani MA, Abi Saab M, Chiantoree M, Mangialajo L, Totti C, Zaghmouri I, Lemée R. 2018. Optimization of sampling, cell collection and counting for the monitoring of benthic harmful algal blooms: Application to Ostreopsis spp. blooms in the Mediterranean Sea. Ecol Indic 91: 116127. DOI: $10.1016 /$ j.ecolind.2018.03.089 
Lehane L, Lewis RJ. 2000. Ciguatera: recent advances but the risk remains. Int J Food Microbiol 61(2-3): 91-125. DOI: 10.1016/S01681605(00)00382-2

Ministry of Forestry and Environment. 2004. Decision on Sea Water Quality Standard No. 51. Ministry of Forestry and EnvironmentRepublic of Indonesia, Jakarta. [Indonesian]

Nagahama Y, Fukuyo Y. 2005. Redescription of Cryptomonas lima collected from Sorrento, Italy, the basionym of Prorocentrum lima. Plankton Biol Ecol 52 (2): 107-109.

Nishimura T, Uchida H, Noguchi R, Oikawa H, Suzuki T, Funaki H, Ihara C, Hagino K, Arimitsu S, Tanii Y, Abe S, Hashimoto K, Mimura K, Tanaka K, Yanagida I, Adachi M. 2019. Abundance of the benthic dinoflagellate Prorocentrum and the diversity, distribution, and diarrhetic shellfish toxin production of Prorocentrum lima complex and $P$. caipirignum in Japan. Harmful Algae 96: 101687. DOI: 10.1016/j.hal.2019.101687.

Oktavian B, Thamrin, Siregar YI. 2017. Analysis of epiphytic dinoflagellates on Thalassia hemprichii at Nirwana Beach Waters, Kabung Bay District, Padang City, West Sumatera Province. Jurnal Online Mahasiswa. [Indonesian]

Seygita V, Thamrin, Siregar YI. 2015. Analisis kelimpahan Dinoflagellata Bentik beracun di Perairan Teluk Bayur, Sumatera Barat. Dinamika Lingkungan Indonesia 2 (2): 92-99. DOI: 10.31258/dli.2.2.p.92-99. [Indonesian]

Skinner MP, Lewis RJ, Morton S. 2011. The abundance of potentially toxic epiphytic dinoflagellates and nutrients from Bali and Gili Trawangan, Indonesia. Mar Res Indones 36 (2): 11-23. DOI: 10.14203/mri.v36i2.38

Sneath PHA. 2005. Numerical taxonomy. In: Brenner DJ, Krieg NR, Staley JT, Garrity GM (eds). Bergey's Manual ${ }^{\circledR}$ of Systematic Bacteriology 2(Pt A): The Proteobacteria, Introductory Essay. Springer, USA.

Susetiono, Pratomo A, Kurniawan D, Susiana. 2016. Monitoring on the Health of the Coral Reef and Related Ecosystem at Bintan District 2014. UMRAH-CRITC-LIPI, Tanjung Pinang. [Indonesian]

deSylva DP. 1994. Distribution and ecology of ciguatera fish poisoning in Florida, with emphasis on the Florida Keys. Bull Mar Sci 54 (3): 944 954.

Tester PA, Kibler SR, Holland WC, Usup G, Vandersea MW, Leaw CP, Teen LP, Larsen J, Mohammad-Noor N, Faust MA, Litaker RW 2014. Sampling harmful benthic dinoflagellates: Comparison of artificial and natural substrate methods. Harmful Algae 39: 8-25. DOI: 10.1016/j.hal.2014.06.009.

Thamrin. 2014. Analysis of benthic dinoflagellate Gambierdiscus, Ostreopsis, and Prorocentrum density on the west coast of Sumatera Island and Bintan Island coast in Riau Archipelago, Indonesia. In:
Hutauruk RM, Heltonika B, Karnila R, Windarti, Syawal H, Efriyeldi (eds). Proceeding of 3rd International Seminar of Fisheries and Marine Science. University of Riau, Pekanbaru, 9-10 October 2014.

Widiarti R. 2002. Epibenthic dinoflagellate on macroalgae at Penjaliran Barat Island reef flat, Jakarta Bay. Sains Indonesia 1 (7): 1-9. [Indonesian]

Widiarti R. 2010. Dinoflagellate which cause Ciguatera Fish Poisoning (CFP) in Belitung Island waters. In: Nababan B (eds). Prosiding Pertemuan Ilmiah Tahunan ISOI VII. Ikatan Sarjana Oseanologi Indonesia, Pangkalpinang, 4 October 2010. [Indonesian]

Widiarti R. 2011. Toxic dinoflagellate, which causes Ciguatera Fish Poisoning in Seribu Islands waters, North Jakarta: Preliminary study on species distribution. In: Nababan B (eds). Prosiding Pertemuan Ilmiah Nasional Tahunan ISOI VIII. Ikatan Sarjana Oseanologi Indonesia, Makassar, 25-27 September 2011. [Indonesian]

Widiarti R, Adi APW. 2016. The potentially toxic benthic dinoflagellate in Pahawang Besar dan Kelagian Kecil Islands, Lampung. In: Nababan B (eds). Prosiding Pertemuan Ilmiah Nasional Tahunan ISOI XII. Ikatan Sarjana Oseanologi Indonesia, Banda Aceh, 10-12 December 2015. [Indonesian]

Widiarti R, Pudjiarto RK. 2015. Dinoflagellata toksik penyebab Ciguatera Fish Poisoning di Perairan Pulau Tidung, Kepulauan Seribu. Jurnal Ilmiah Ilmu Biologi 1 (1): 5-8. [Indonesian]

Widiarti R, Pudjiarto RK, Pratama I. 2016a. Potentially toxic benthic dinoflagellate in Gili Meno and Gili Air waters, Lombok. In: Setyawan AD, Sugiyarto, Pitoyo A, Sutomo, Widiastuti A, Windarsih G (eds). Prosiding Seminar Nasional Masyarakat Biodiversitas Indonesia. Universitas Sebelas Maret, Surakarta, 7 November 2015. [Indonesian]

Widiarti R, Pudjiarto RK, Fathoniah I, Adi APW. 2016b. Epiphytic dinoflagellate on macroalgae which potentially cause Ciguatera Fish Poisoning in Weh Island waters, Aceh. In: Setyawan AD, Sugiyarto, Pitoyo A, Sutomo, Widiastuti A, Windarsih G. (eds). Prosiding Seminar Nasional Masyarakat Biodiversitas Indonesia 2 (1) Universitas Sebelas Maret, Surakarta, 23 April 2016. [Indonesian]

Widiarti R, Zamani NP, Bengen DG, Madduppa H. 2018. The dinoflagellate causing ciguatera fish poisoning, Prorocentrum lima, in Karimunjawa island waters-Central Java. IOP Conf Ser: Earth Environ Sci 325: 012014. DOI: 10.1088/1755-1315/325/1/012014

Yusuf M. 2013. Coral reef condition and fish potency in Karimunjawa National Park waters, Jepara District. Bull Oseanografi Mar (2): 5460. [Indonesian]

Zhang H, Li Y, Cen J, Wang H, Cui L, Dong Y, Lu S. 2015. Morphotypes of Prorocentrum lima (Dinophyceae) from Hainan Island, South China Sea: Morphological and molecular characterization. Phycol 54 (5): 503-516. 